\title{
ROBOT-OPERATED INSPECTION OF AIRCRAFT ENGINE TURBINE ROTOR GUIDE VANE SEGMENT GEOMETRY
}

\author{
Andrzej Burghardt, Krzysztof Kurc, Dariusz Szybicki, Magdalena Muszyńska, Tomasz Szczęch
}

Original scientific paper

This paper presents a method for robot-assisted geometrical inspection of an aircraft engine turbine stator segment employing the ABB IRB 1600 robot, equipped with the Atos Core 3D scanner and interfaced with the Atos Professional software suite. The geometrical inspection is a preliminary geometrical verification of a thin-wall casting against a CAD-generated nominal model. If the casting geometry tolerances are met, characteristic coordinates of points across the casting are determined for their further adaptation during an alternative robot-assisted vane wall thickness measurement, which is done with the ABB IRB 140 robot and by employing the UTT method.

Keywords: aircraft engine; casting; guide vane; robot; $3 D$ scanner

\section{Robotom upravljana kontrola geometrije segmenta statorske lopatice rotora turbine avionskog motora}

Izvorni znanstveni članak

U radu je prikazana metoda robotom upravljane kontrole geometrije jednog segmenta statora turbine avionskog motora, primjenom ABB IRB 1600 robota, opremljenog Atos core 3D skenerom u sučelju s Atos Professional softverskim paketom. Kontrola geometrije preliminarna je geometrijska verifikacija odljevka tankih stijenki u odnosu na CAD-generirani nominalni model. Ako su zadovoljene tolerancije geometrije odljevka, određuju se karakteristične koordinate točaka na odljevku za njihovu daljnju prilagodbu tijekom alternativnog mjerenja debljine stijenke lopatice uz pomoć robota, što je učinjeno s ABB IRB 140 robotom primjenom UTT metode.

Ključne riječi: avionski motor; odljevak; 3D skener; robot; statorska lopatica

\section{Introduction}

Stators (Fig. 1) are manufactured by precision vacuum casting. Low thrust aircraft engines feature monolithic stator castings with a number of vanes which range from ten-odd to several dozens. The processing conditions of casting make it difficult to manufacture large stators for large aircraft engines. In this case, a stator is built as an assembly of ten-odd segments, each with 3 to 6 vanes (Fig. 2). The casting weight is decisive when selecting the stator casting method. A reduction of the casting weight forces thin-wall cored casting with the wall thickness below $1.0 \mathrm{~mm}$. Given their manufacturing difficulty, complexity and technical requirements, these castings are among the most technologically advanced products and are usually protected (along with their manufacturing technology) as the intellectual property of the manufacturer; hence they are not widely published.

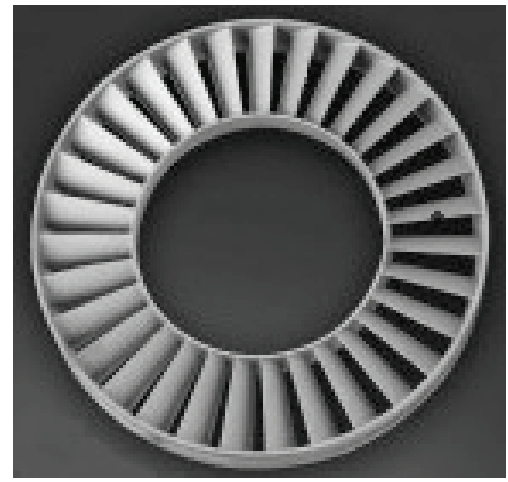

Figure 1 Stator

The turbine rotor guide vanes (the stator) of a turbofan engine are highly exposed to dynamic loads from the hot gas stream, the temperature of which ranges from $950{ }^{\circ} \mathrm{C}$ to $1650{ }^{\circ} \mathrm{C}[2,8]$. Hence, it is essential to improve the high temperature resistance of the components with ceramic thermal barriers and by cooling the stator during operation they are not widely published. The cooling process is made possible by means of internal vane channels made in complex cored casting processes. The internal channels pass a cooling medium. Being hollow, they also reduce the engine weight. Currently, the main objective in design engineering of next generation aircraft engines and their parts is to reduce fuel consumption, emission levels of harmful substances in exhaust gases, and noise levels generated by the power plant. The component weight is reduced and the stator segment and vane cooling system performance is improved by making the vane casting walls thinner. It is then critical to assure dimensional repeatability of wall thickness during the manufacturing process. Among the available NDT (nondestructive test) methods applied in the wall section inspection $[3,4,6]$ is ultrasonic testing.

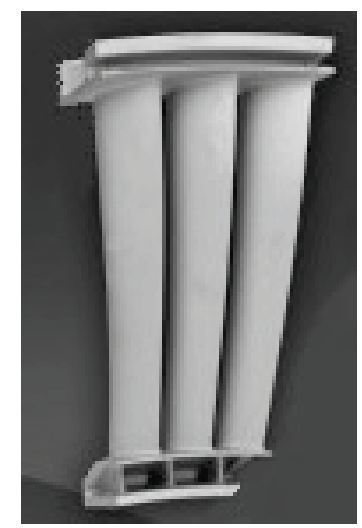

Figure 2 Stator segment

Precision-made polycrystalline castings of large thinwall segments for the turbine stator of the GP7200 nextgeneration aircraft engine of the Airbus A380 are prone to 
deformation at the casting solidification stage. Hence, 20 $\%$ of these products end up as casting defects, which is caused by many factors. This is why each casting needs to pass control.

Pratt \& Whitney Rzeszów Sp. z o.o. does the initial geometrical inspection with tactile sensors and three possible classifications of results: the casting is good, the casting is to be reworked (straightened), or the casting is defective. The stators qualified for downstream inspection must pass stages of successive measurements of vane wall thickness. The measurements are done by manual ultrasonic testing. The process involves determination of 28 specific measurement points on each vane with a template, and a handheld flaw detector is applied to measure the vane wall thickness at each of the determined points. This solution is labour intensive and has a long processing time.

\section{Robot-assisted geometrical inspection}

The robot-assisted geometrical inspection is performed with the ABB IRB 1600 robot manipulator equipped with the Atos Core 135 3D scanner (Fig. 3) and the Atos Professional control and measurement software suite. The ABB IRB 1600 allows liberal and automatic positioning of the $3 \mathrm{D}$ scanner in front of the inspected part [1].
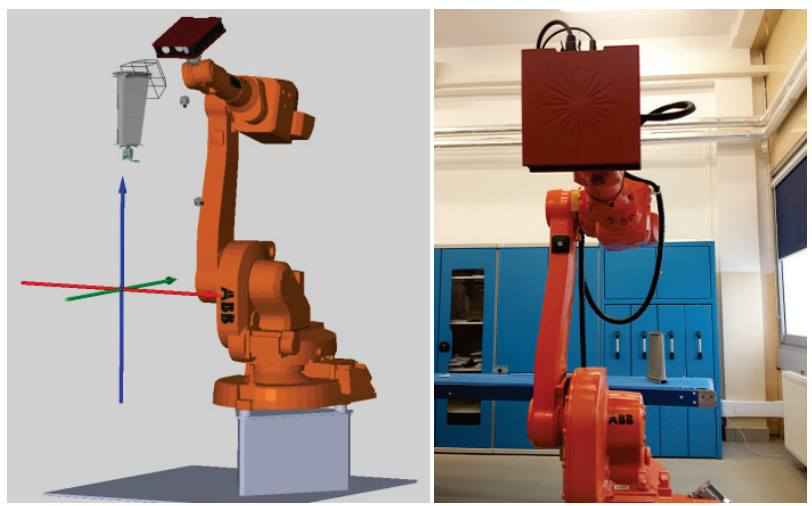

Figure 3 Virtual and actual laboratory geometrical inspection stand

The Atos Professional software suite can save the spatial measurement positions and orientations of the 3D scanner in order to automate and provide repeatability of successive component inspection runs. When each measurement is complete, the scanner must be moved and rotated to areas not recorded in the preceding scanning run. The individual measurements are automatically processed within a common coordinate system, which produces a complete cloud of 3D points.

The Atos Core 3D scanner is a system of stereoscopic cameras which work by triangulation (i.e. calculation of the intersection of a specific plane with a ray in threedimensional space). The scanner projects a system of bands on the inspected surface of the piece. The projected bands are recorded by the two stereoscopic cameras (Fig. 4), providing a phase shift image from the sine distribution of intensity on the camera detectors. Atos Core uses multiple heterodyne phase shifts to assure the maximum sub-pixel accuracy. Separate 3D coordinates are calculated for each camera detector pixel from optical transformation equations.

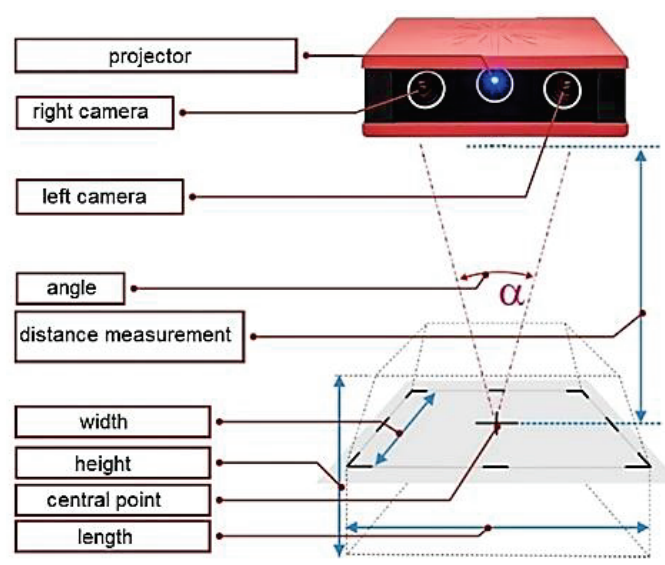

Figure 4 Atos Core measurement concept

This gives a calculated polygonal grid which circumscribes free surfaces and geometrical elements. The polygonal grid is verified by comparing the reproduced surface to the engineering drawing or directly to a set of CAD data $[5,7]$. The software can also implement 3D surface analysis and 2D analysis of sections or points.

The detailed inspection results can be presented in reports that may include screenshots, measurement charts, diagrams, text and graphic elements. The results can be represented in a graphical format, edited in the user interface, or exported to PDF files.

\section{Initial casting verification}

A number of unfavourable phenomena occur during the solidification of large thin-wall polycrystalline castings of stator segments. They include shrinkage, stress, and ultimately, deformation. Once cleaned, the casting is subjected to a preliminary visual inspection. If the casting passes, it is scanned to produce a complete cloud of 3D points. Atos Professional has an efficient feature called Fast Inspection which facilitates displaying a colour map of deviations from the preset geometrical tolerances (Fig. 5) and inspecting the measurement features in real time, directly after each scanning run. The measured results are updated and displayed during the measurement cycle in relation to an imported or manually input measurement plant and a CAD model.

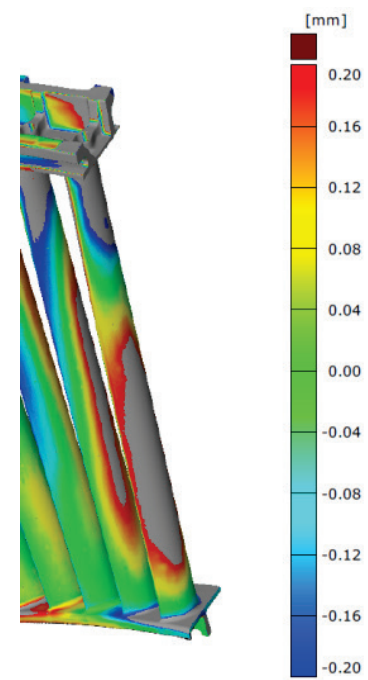

Figure 5 Colour map of preset geometrical tolerance deviations 
The quality control functions during the analysis of airfoils and turbine vanes or blades include the checks of: camber line, geometrical solid mass centre, turbine blade and vane profile thickness, chords, twisting angle, attack radius, trail radius, etc. For the inspection of castings, a program was developed that generates 42 sections of stator segment vanes, and a comparison of the CAD model with the generated $3 \mathrm{D}$ point cloud, the camber line was reproduced at the selected points of vane section components with geometrical tolerance deviations (Fig. $6)$.

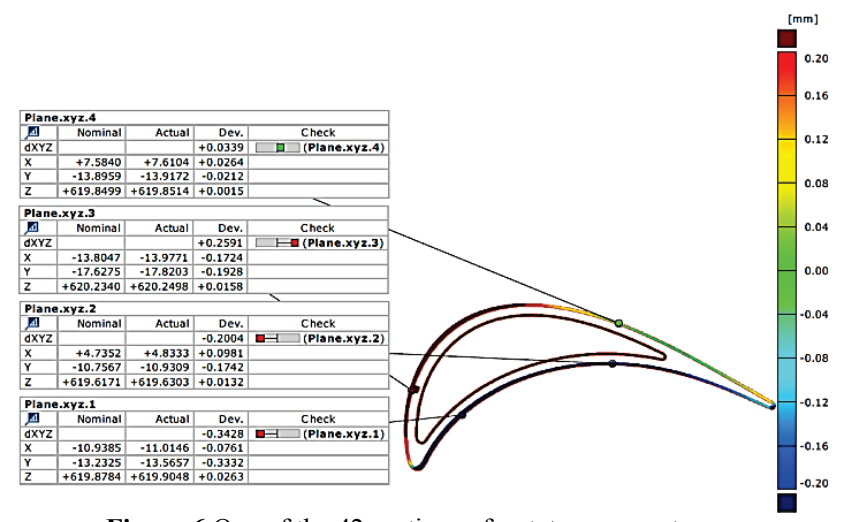

Figure 6 One of the 42 sections of a stator segment vane

The 3D point cloud fitted to the CAD model as above will be used downstream to determine the actual coordinates of measurement points required to verify the vane wall thickness.

\section{Determination of actual measurement point coordinates}

Each of the stator vanes is a precision thin-wall casting and requires a verification of wall thickness at 28 measurement points. The points are determined with utmost precision, and currently the inspection process requires marking them manually with a special template. This method has been acceptable so far, since the vane wall thickness has been measured manually, with a handheld flaw detector. If the section thickness inspection process is conducted with a robot and the UTT method, the points must be input into a controller to achieve their locations and for them to be measured. Hence the coordinates of the points were produced from the 3D scan (the $3 \mathrm{D}$ point cloud) generated as explained above.

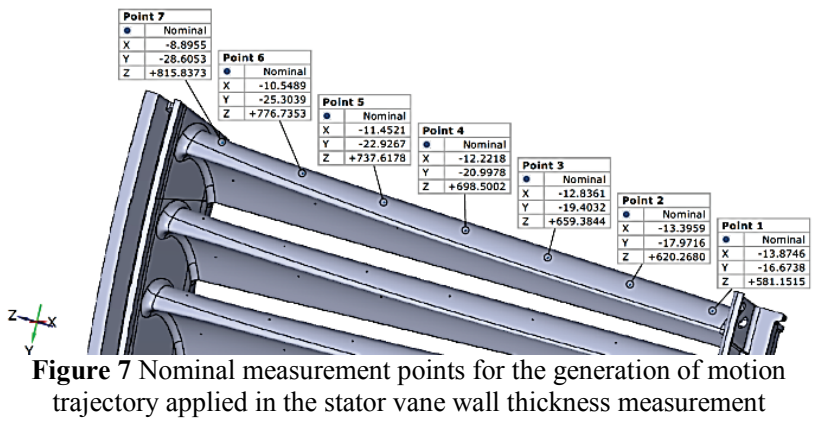

The nominal piece (the CAD model) had the nominal coordinates determined (Fig. 7) for the first 7 points on a vane of the inspected stator and the actual coordinates for the actual casting were generated automatically (Fig. 8).
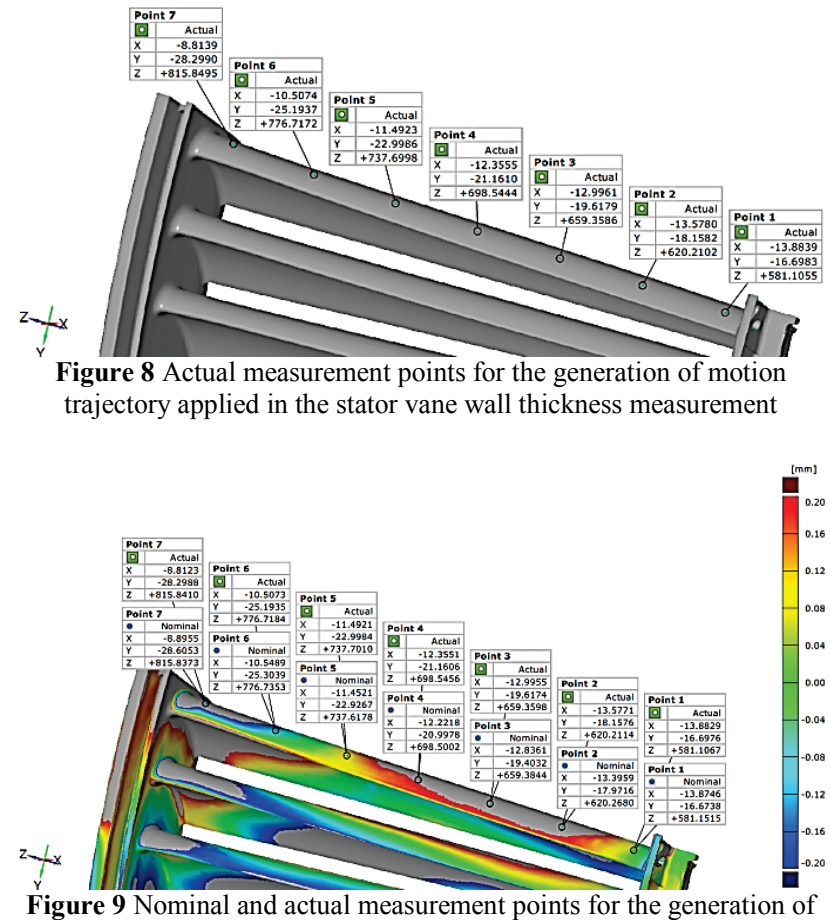

Figure 9 Nominal and actual measurement points for the generation of motion trajectory applied in the stator vane wall thickness measurement

The origin of the coordinate system was selected (offset) during the determination of the actual coordinates of the geometrical measurement system (Fig. 3) to match the coordinate system applied to measure the vane wall thickness (Fig. 10).

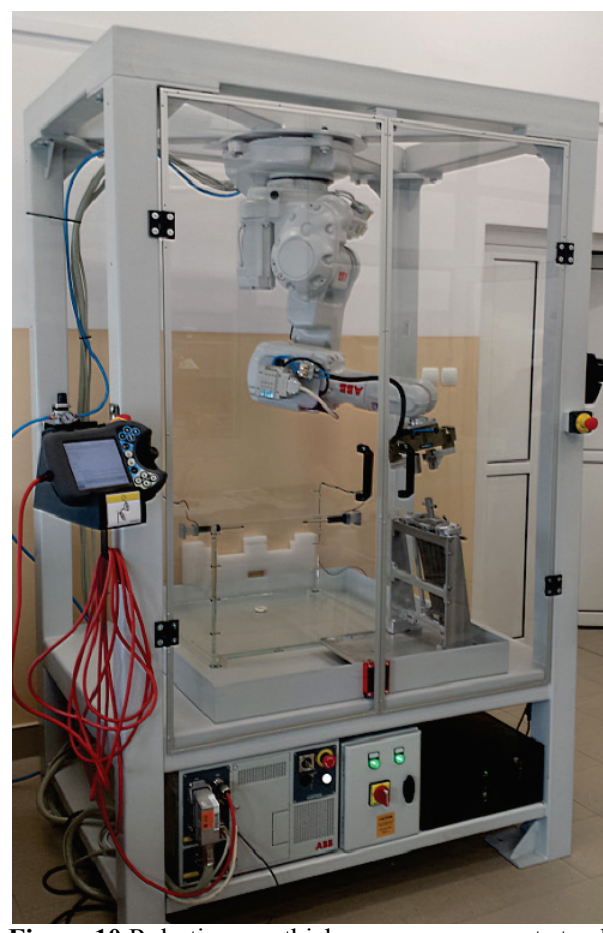

Figure 10 Robotic vane thickness measurement stand

Hence, 168 specific coordinates of the actual measurement points referenced to the nominal points (Fig. 9) are produced for a single complete part of the stator and are input to the controller of the robotic measurement 
stand (Fig. 10). The specific coordinates permit generation of the motion trajectory for the ABB IRB 140 to perform the UTT measurement.

\section{Conclusions}

This paper presents a robotic geometrical inspection stand equipped with a scanner device, a GOM software suite and an ABB robot. The paper discusses a method of automatic geometry scanning, and the results produced by that process are compared against a measurement model (nominal) to perform an initial geometry verification of a casting and determine 168 specific coordinates of the actual measurement points that are necessary to generate the motion trajectory for the other robotic test stand which does a UTT measurement of precision thin-wall casting of vanes. The correctness of the developed solution has been proven with a series of demonstration scans and measurements of two turbine rotor guide vanes segments of an aircraft engine provided by courtesy of Pratt \& Whitney Rzeszów Ltd.

\section{Acknowledgements}

The authors gratefully acknowledge the funding of the Polish National Centre for Research and Development. The project was realized within the frames of the Program DEMONSTRATOR PLUS UOD-DEM-1$557 / 001$.

\section{References}

[1] Burghardt, A.; Kurc, K.; Muszyńska, M.; Szybicki, D. Zrobotyzowane stanowisko weryfikacji procesów obróbki. // Modelowanie inżynierskie. 52(2014), pp. 23-29.

[2] Carl, V.; Becker, E.; Sperling, A. Thermography inspection system for gas turbine blades. // Proceedings $7^{\text {th }}$ European Conference on NDT. Copenhagen, 1998, pp. 2658-2665.

[3] Kilian, D. 3D tomography of turbine blades. // Proceedings of the International Symposium of Computerized Tomography for Industrial Applications. Berlin, 31(1999), pp. 1-17.

[4] Lane, C. The Development of a 2D Ultrasonic Array Inspection for Single Crystal Turbine Blades. // Springer Theses. Springer International Publishing, 2014, Switzerland, pp. 63-79. https://doi.org/10.1007/978-3-319-02517-9

[5] Lavoué, G.; Tola, M.; Dupont, F.; MEPP-3D Mesh Processing Platform. // In: GRAPP/IVAPP. 2012, pp. 206210.

[6] Le Bihan, Y.; Joubert, P.; Placko D. Wall thickness evaluation of single crystal hollow blades by eddy current sensor. // ND\&E International. 34(2001), pp. 363-368. https://doi.org/10.1016/S0963-8695(00)00074-8

[7] Liu, B.; Luo, X.; Huang, R.; Yue, Z. Virtual plate prebending for the long bone fracture based on axis prealignment. // Computerized Medical Imaging and Graphics. $38,4(2014)$, pp. 233-244. https://doi.org/10.1016/j.compmedimag.2014.02.002

[8] Sieniawski, J. Nickel and titanium alloys in aircraft turbine engines. // Advances in Manufacturing Science and Technology. 27(2003), pp. 23-34.

\section{Authors' addresses}

Andrzej Burghardt, PhD Eng.

The Faculty of Mechanical Engineering and Aeronautics, Department of Applied Mechanics and Robotics, Rzeszow University of Technology

8 Powstanców Warszawy St., 35-959 Rzeszow, Poland

E-mail: andrzejb@prz.edu.pl

Krzysztof Kurc, PhD Eng.

The Faculty of Mechanical Engineering and Aeronautics, Department of Applied Mechanics and Robotics, Rzeszow University of Technology

8 Powstanców Warszawy St., 35-959 Rzeszow, Poland

E-mail: kkurc@prz.edu.pl

Dariusz Szybicki, PhD Eng.

The Faculty of Mechanical Engineering and Aeronautics, Department of Applied Mechanics and Robotics, Rzeszow University of Technology 8 Powstanców Warszawy St., 35-959 Rzeszow, Poland E-mail: dszybick@prz.edu.pl

Magdalena Muszyńska, PhD Eng.

The Faculty of Mechanical Engineering and Aeronautics, Department of Applied Mechanics and Robotics,

Rzeszow University of Technology

8 Powstanców Warszawy St., 35-959 Rzeszow, Poland

E-mail:magdaw@prz.edu.pl

Szczęch Tomasz, MSc. Eng.

Pratt \& Whitney Reszow S.A.,

120 Hetmanska St., 35-078 Rzeszow, Poland

E-mail: tomasz.szczech@wskrz.com 